\title{
MODEL PENCIPTAAN LAPANGAN KERJA MELALUI PENGEMBANGAN EKONOMI LOKAL PADA KECAMATAN SAMARINDA ILIR
}

\author{
Indah Martati \\ Suminto \\ Andi Syarifuddin \\ Program Studi S-1 Terapan Manajemen Pemasaran, Politeknik Negeri Samarinda \\ Email: iin_polsam@yahoo.com; mints_polnes@yahoo.com; andys_polnes@yahoo.com
}

\begin{abstract}
Abstrak
Penelitian ini dilaksanakan pada 13 desa di Kecamatan Samarinda Ilir dengan obyek potensi usaha masyarakat. Tujuan penelitian adalah untuk mengidentifikasi potensi sumberdaya ekonomi lokal yang berdaya tarik, berdaya saing tinggi dan berpotensi menciptakan lapangan pekerjaan. Data dikumpulkan melalui focus group discussion dengan masyarakat. Metode analisis yang digunakan adalah analisis deskriptif kualitatif. Hasil penelitian menunjukkan bahwa usaha ekonomi produktif unggulan yang berpeluang besar membuka lapangan kerja adalah sektor perdagangan, industri rumah tangga, jasa dan pertanian.
\end{abstract}

Kata kunci: Ekonomi lokal, daya saing, daya tarik, lapangan kerja.

\begin{abstract}
This study was conducted in 13 villages in the district with the object Samarinda Ilir the business potential. The goal of this study is to identify the potential resource of the local economy that highly attractive, competitive and potentially to create jobs. Data were collected through focus group discussion with the community. The analysis method used is descriptive qualitative analysis. The results showed that the economically productive featured most likely to create jobs is trade, home industry and services and agriculture.
\end{abstract}

Keywords: Local economy, competitiveness, attractiveness, employment.

\section{PENDAHULUAN}

Selama Maret-September 2012 jumlah penduduk miskin di Kalimantan Timur hanya turun 7.200 orang dari 253.340 orang $(6,6 \%)$ menjadi 246.110 orang $(6,38 \%)$. Penurunan angka kemiskinan di Kaltim belum sampai di atas $1 \%$ atau belum signifikan. Penurunan orang miskin sebanyak 7.200 orang atau hanya $0,3 \%$ (Zaini, 2013). Daerah yang mampu mencapai di bawah rata-rata provinsi salah satunya adalah Samarinda. Upaya Pemerintah Kota Samarinda untuk membantu masyarakat miskin bangkit, yakni dengan mencerdaskan anak-anak dari keluarga miskin. Pada 17 Januari 2013 Pemerintah Kota Samarinda membagikan 2.564 kartu Rumah Tangga Sangat Miskin (RTSM) kepada masyarakat di tujuh kecamatan yakni Palaran, Samarinda Seberang, Samarinda Ulu, Samarinda Ilir, Samarinda Utara, Sungai Pinang dan Sambutan (Syahari, 2013).
Penyebab tingginya angka kemiskinan disebabkan oleh banyaknya pendatang yang tidak berbekal keterampilan serta banyaknya lulusan sekolah dan perguruan tinggi yang tidak tertampung di lapangan pekerjaan (Indra, 2009). Selain itu, tingginya angka kemiskinan juga disebabkan oleh banyaknya perusahaan di sektor perkayuan yang mengalami pailit, sehingga mem-PHK karyawannya dan mengakibatkan bertambahnya jumlah pengangguran.

Berbagai usaha penanggulangan kemiskinan yang telah dijalankan pemerintah sampai saat ini belum membuahkan hasil yang optimal. Hal tersebut disebabkan program yang dijalankan belum langsung mengena pada akar masalah kemiskinan itu sendiri. Pemerintah gagal menangkap profil kemiskinan dari karakteristik sosial-budaya dan karakteristik demografinya, seperti tingkat pendidikan, cara memperoleh fasilitas kesehatan, jumlah anggota keluarga, cara memperoleh air bersih dan lain sebagainya. Peme- 
rintah juga gagal mencermati profil kemiskinan dari karakteristik ekonomi, seperti sumber pendapatan, pola konsumsi/pengeluaran, tingkat beban tanggungan dan lain-lain.

Salah satu usaha untuk mengatasi masalah kemiskinan yang efektif sesuai rekomendasi ILO No 189 tahun 1998 tentang General conditions for the promotion of job creation through small and mediumsized enterprises adalah dengan penciptaan lapangan kerja. Akses ke lapangan pekerjaan adalah jalan yang paling menjamin untuk bisa keluar dari kemiskinan. Dengan demikian, kebijakan dan program penciptaan lapangan kerja tetap memainkan peran penting dalam memerangi kemiskinan. Rekomendasi tersebut sebagai dasar untuk mengubah dan meninggalkan model pengentasan kemiskinan yang bersifat topdown dari pemerintah terhadap masyarakat miskin menjadi buttom-up. Semua kebijakan yang diambil pemerintah harus pro-poor (ILO, 2004).

Berdasarkan rekomendasi ILO No. 189, maka peneliti mencoba untuk menerapkan model penciptaan lapangan kerja melalui pengembangan ekonomi lokal pada Kecamatan Samarinda Ilir karena daerah Samarinda Ilir masih menduduki peringkat kedua untuk keluarga miskin dengan angka $6.050 \mathrm{KK}$ (Sade, 2010). Permasalahan utama pada penelitian ini adalah sektor dan produk unggulan apa yang merupakan potensi sumberdaya ekonomi lokal yang berdaya tarik dan berdaya saing tinggi yang dapat membuka lapangan kerja bagi masyarakat di Samarinda Ilir?

Penelitian ini dilaksanakan dengan tujuan untuk mengidentifikasi potensi sumberdaya ekonomi lokal yang berdaya tarik dan berdaya saing tinggi yang dapat menciptakan lapangan pekerjaan, mengidentifikasi sektor usaha unggulan di setiap desa dan menemukenali usaha ekonomi produktif dan produk unggulan.

Hasil penelitian ini diharapkan dapat memberikan kontribusi sebagai model penciptaan lapangan pekerjaan melalui pengembangan ekonomi produktif berbasis potensi ekonomi lokal dan terwujudnya peningkatan pendapatan masyarakat, berkurangnya pengangguran, menurunnya tingkat kemiskinan.

\section{LANDASAN TEORI}

Peluang untuk mengembangkan potensi sumberdaya masyarakat lokal masih besar meskipun tantangan yang dihadapi juga cukup besar. Tantangan tersebut berkaitan dengan kapasitas sumber daya manusia, modal, jaringan kerja dan jaringan pemerintah. Namun, beberapa ahli perekonomian rakyat (Korten, 1988; Mubyarto, 1984; Ismawan, 1992;
Sarman \& Sajogyo, 2000) secara eksplisit mengemukakan bahwa perencanaan yang berpusat pada masyarakat dalam perencanaan program, menempatkan masyarakat sebagai subyek untuk mengenali permasalahan, potensi dan secara swadaya akan tercapai kemandirian dalam mengatasi permasalahan mereka. Afifi (2007) mengaitkan pengembangan ekonomi lokal sebagai sebuah strategi pengentasan kemiskinan, masyarakat miskin sebagai aset yang berpotensi menjadi kekuatan besar dalam memacu perkembangan ekonomi daerah jika potensi insaniah dapat dimobilisasi dan dikembangkan.

Hasil penelitian Suyono (2006) menemukan bahwa program kemitraan bagi pengembangan ekonomi lokal (KPEL) secara statistik berpengaruh positif terhadap pendapatan petani budidaya ulat sutera di Kabupaten Wonosobo. Implikasi dari penelitian ini adalah bahwa pemberantasan kemiskinan di daerah bisa dilakukan dengan program kemitraan bagi pengembangan ekonomi lokal. Sementara Blakely \& Bradshaw (2002) melihat PEL sebagai proses yang mana pemerintah lokal dan organsisasi masyarakat terlibat untuk mendorong, merangsang, memelihara, aktivitas usaha untuk menciptakan lapangan pekerjaan.

Selanjutnya Indratno \& Agustina (2005) menyatakan bahwa PEL merupakan salah satu langkah dalam pengentasan kemiskinan. Pengentasan kemiskinan dengan pendekatan pengembangan ekonomi lokal dapat mendorong, merangsang, terciptanya jiwa kewirausahaan pada masyarakat dan tumbuhnya potensi ekonomis dari aset daerah. Untuk mengatasi masalah kemiskinan diperlukan suatu model yang tepat, efektif dan efisien diwujudkan dalam berbagai program pemberdayaan yang terpadu dan berkesinambungan. Model pengembangan ekonomi lokal tidak terlepas dari usaha untuk mengakomodasi aspirasi dan kebutuhan riil masyarakat miskin.

Tujuan pengembangan ekonomi lokal adalah menciptakan pertumbuhan ekonomi yang semakin tinggi dan berkelanjutan serta kesempatan kerja penuh melalui meningkatnya kegiatan investasi di daerah. Pengembangan ekonomi lokal tidak semata menekankan pada aspek ekonomi, tetapi lebih pada pendekataan kemitraan dan kerjasama para pihak baik pemerintah, pengusaha dan organisasi masyarakat lokal. Oleh karena itu seluruh pelaku pembangunan harus terlibat dalam proses diagnosis, perencanaan, pelaksanaan dan pengendalian kegiatan dalam kerangka pengembangan ekonomi lokal.

Dendi \& Mahman (2007) mengatakan bahwa pendekatan pengembangan ekonomi lokal (PEL) yang digunakan sangat tergantung kepada potensi, 
peluang dan persoalan yang dihadapi daerah. Namun demikian, terdapat beberapa pendekatan PEL yang dapat dipilih atau dikombinasikan yang dianggap sebagai menu dasar. Ada lima menu dasar PEL, yaitu pendekatan klaster, pendekatan kemitraan publik swasta, pendekatan usaha kecil, pendekatan regional dan pendekatan rantai nilai.

Jadi pengembangan ekonomi lokal dapat dikatakan sebagai suatu usaha penguatan daya saing yang dapat diarahkan untuk pengembangan dan penguatan ekonomi daerah. Pengembangan tersebut dilakukan untuk pemulihan perekonomian yang didasarkan pada potensi ekonomi produktif dan mandiri melalui keterlibatan berbagai elemen masyarakat (stakeholders) dalam mendorong dan memelihara unit usaha serta penciptaan lapangan kerja baru. Stakeholders tersebut terdiri atas perorangan, perusahaan dan atau organisasi kemasyarakatan, sektor swasta dan sektor nirlaba yang mempunyai minat dan kemampuan untuk mendukung pengembangan masyarakat.

\section{METODE PENELITIAN}

Model rancangan penelitian untuk pengembangan ekonomi lokal dimulai dengan identifikasi potensi sumberdaya ekonomi lokal yang memiliki daya tarik dan daya saing tinggi serta berpontensi menciptakan lapangan pekerjaan. Dilanjutkan dengan upaya menemukenali usaha ekonomi produktif unggulan di setiap desa dan berbagai permasalahan penghambat upaya pengembangan produk unggulan. Dari hasil identifikasi tersebut sebagai dasar untuk menentukan model penciptaan lapangan kerja bagi masyarakat miskin khususnya melalui pengembangan ekonomi lokal di Kecamatan Samarinda Ilir. Kerangka penelitian tersebut dimuat pada Gambar 1.

Populasi penelitian adalah penduduk Kecamatan Samarinda Ilir sebanyak 120.535 jiwa (BPS, 2010). Fokus penelitian pada potensi usaha masyarakat Samarinda Ilir yang didukung dengan data lingkungan, kewilayahan, sosial, ekonomi dan budaya serta demografi. Sampel yang dipilih adalah kelompok usaha kecil masyarakat di sektor dagang, jasa, industri rumah tangga, pertanian, peternakan di tiga belas (13) desa/kelurahan di wilayah Kecamatan Samarinda.

Data yang diperlukan berupa data primer dan data sekunder. Data primer yakni data yang diperoleh langsung dari masyarakat tentang potensi ekonomi lokal dan pola pencaharian masyarakat setempat di 13 desa/kelurahan yang ada di wilayah kecamatan

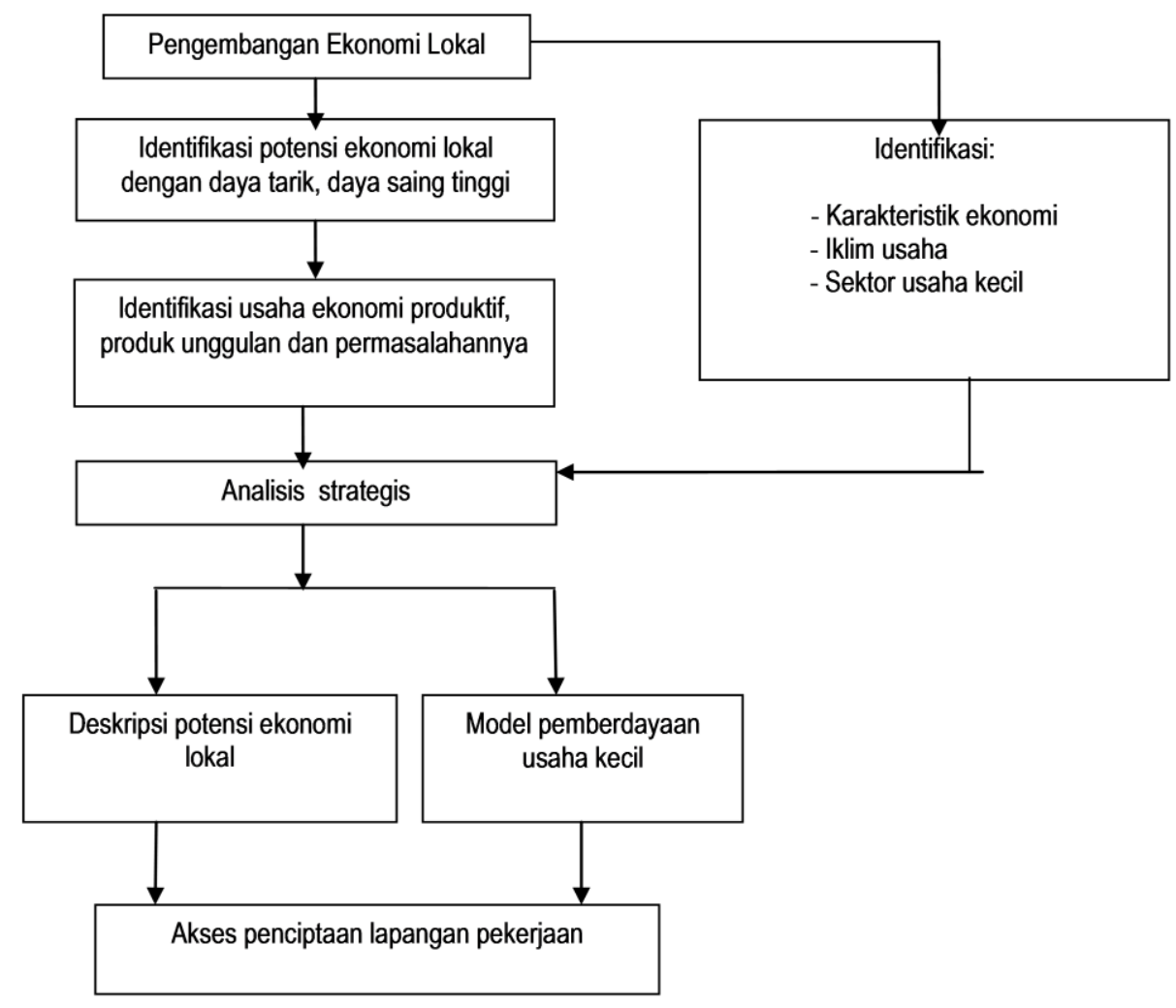

Gambar 1. Kerangka Penelitian 
Samarinda Ilir. Metode yang digunakan untuk menggali data primer melalui focus group discussion $(F G D)$. Data sekunder merupakan sumber data penelitian yang diperoleh peneliti secara tidak langsung melalui media perantara (diperoleh dan dicatat oleh pihak lain). Data sekunder berupa datadata kependudukan, pembangunan sosial kemasyarakatan, lingkungan kewilayahan diperoleh dari informasi baik yang dipublikasikan maupun tidak dipublikasikan oleh Pemerintah Kota Samarinda.
Data sekunder dikumpulkan dengan cara dokumentasi dan checklist terhadap matrik interaksi potensi dasar maupun potensi turunan yang disebarkan ke masyarakat.

Metode analisis yang digunakan adalah analisis deskriptif kualitatif, yakni metode kajian yang meneliti suatu keadaan dengan tujuan membuat deskripsi dan gambaran secara sistematis, faktual dan akurat mengenai fakta-fakta di lapangan serta melakukan pengkajian hubungan antar fenomena yang

Tabel 1. Hasil Identifikasi Akar Masalah Menurut Sektor

\begin{tabular}{|c|c|}
\hline Sektor & Daftar Akar Masalah \\
\hline \multirow{7}{*}{$\begin{array}{l}\text { 1. Sumber daya alam dan } \\
\text { lingkungan }\end{array}$} & 1. Banjir \\
\hline & 2. Air bersih kurang memadai \\
\hline & 3. Tempat pembuangan dan pengolahan sampah belum memadai \\
\hline & 4. Erosi dan tanah longsor \\
\hline & 5. Daya dukung lingkungan menurun \\
\hline & 6. Penebangan liar \\
\hline & 7. Penambangan liar \\
\hline \multirow{6}{*}{$\begin{array}{l}\text { 2. Kependudukan dan } \\
\text { pemukiman }\end{array}$} & 1. Lemahnya kordinasi khususnya dalam hal pendataan, pendanaan, kelembagaan \\
\hline & 2. Matapencaharian berorintasi di sektor informal \\
\hline & 3. Sarana kelistrikan belum memadai \\
\hline & 4. Sarana air bersih belum memadai \\
\hline & 5. Sanitasi lingkungan kurang memadai \\
\hline & 6. Rentan kebakaran \\
\hline \multirow{12}{*}{$\begin{array}{l}\text { 3. Pertanian, peternakan, } \\
\text { perikanan, perkebunan }\end{array}$} & 1) Irigasi belum memadai \\
\hline & 2) Kualitas SDM pertanian belum optimal \\
\hline & 3) Pembinaan petani oleh instansi teknis belum memadai \\
\hline & 4) Dukungan kebijakan pembangunan berkelanjutan belum optimal \\
\hline & 5) Tempat penampungan hasil bumi dan kerajian masyarakat belum memadai \\
\hline & 6) Biaya faktor produksi tinggi \\
\hline & 7) Kesuburan tanah menurun \\
\hline & 8) Rendahnya harga jual hasil produksi di tingkat petani \\
\hline & 9) Teknologi budidaya yang masih konvensional \\
\hline & 10) Akses pemasaran hasil produksi rendah \\
\hline & 11) Masalah hama dan gulma \\
\hline & 12) Konflik lahan \\
\hline \multirow{12}{*}{$\begin{array}{l}\text { 4. Industri, dagang, jasa dan } \\
\text { kelembagaan lainnya }\end{array}$} & 1) Lemahnya integrasi program pemerintah-dunia usaha-masyarakat \\
\hline & $\begin{array}{l}\text { 2) Lemahnya kordinasi antar program pengentasan kemiskinan diantara instansi pemerintah } \\
\text { pusat dan daerah. }\end{array}$ \\
\hline & 3) Belum optimalnya fungsi kelembagaan pemerintah, dunia usaha, LSM, dan masyarakat. \\
\hline & 4) Produktivitas usaha masih rendah \\
\hline & 5) Belum ada standarisasi kualitas \\
\hline & 6) Pemasaran mengalami kesulitan/terbatas \\
\hline & 7) Pelatihan ketrampilan kurang \\
\hline & 8) Pembinaan industri rumah tangga secara berkelanjutan masih rendah \\
\hline & 9) Kemampuan daya saing rendah \\
\hline & 10) Sulit memperoleh modal usaha \\
\hline & 11) Ketrampilan SDM kurang \\
\hline & 12) Tehnologi usaha tani masih tradisional \\
\hline \multirow{5}{*}{$\begin{array}{l}\text { 5. Infrastruktur fisik dan } \\
\text { sosial }\end{array}$} & 1) Kualitas sarana jalan masih rendah \\
\hline & 2) Ketersediaan drainase yang kurang memadai \\
\hline & 3) Jaringan infrastruktur fisik dan sosial masih kurang \\
\hline & 4) Anggaran pembangunan dan pemeliharaan terbatas \\
\hline & 5) Peran LPM yang belum maksimal \\
\hline
\end{tabular}


diselidiki dari hasil diskusi kelompok terfokus. Analisis dilakukan untuk mengidentifikasi potensi sumberdaya ekonomi lokal yang mampu membuka peluang kerja bagi masyarakat miskin. Kekuatan usaha ekonomi produktif di setiap desa merupakan sektor usaha unggulan yang menjadi model penciptaan lapangan kerja.

\section{HASIL PENELITIAN DAN PEMBAHASAN}

Faktor penghambat berkembangnya usaha yang menjadi mata pencaharian masyarakat Samarinda Ilir dari hasil $F G D$ dikelompokkan menjadi lima (5) sektor. Akar masalah dari setiap sektor seperti tertera pada Tabel 1.

Hasil $F G D$ dapat direkam potensi dasar, potensi turunan atas sumberdaya ekonomi lokal yang dimiliki masyarakat Kecamatan Samarinda Ilir yang dilihat dari aspek kelompok strategis pelaku usaha seperti ditampilkan pada Tabel 2.

Berbagai kebutuhan yang diperlukan untuk mengembangkan usaha sumber mata pencaharian masyarakat Kecamatan Samarinda Ilir dapat dikelompokkan menjadi delapan (8) kebutuhan yaitu:
1) Pemberdayaan.

Potensi sumberdaya manusia perlu diberdayakan dalam pengelolaan dan pengembangan potensi ekonomi lokal di setiap desa/kelurahan. Pemberdayaan masyarakat diharapkan mampu mengurangi pengangguran dan meningkatkan pendapatan masyarakat.

2) Bantuan modal usaha

Bantuan modal usaha sangat dinantikan oleh setiap kelompok strategis usaha yang menjadi mata pencaharian masyarakat Samarinda Ilir yang mayoritas masuk kategori usaha kecil.

3) Kestabilan harga dan ketersediaan saprodi

Bagi para petani sangat berharap Pemerintah Kota Samarinda mengambil langkah strategis sebagai upaya menjaga kestabilan harga saprodi. Dengan stabilnya harga saprodi dapat membantu petani meningkatkan produktivitas hasil pertaniannya. Kelompok usaha ini juga memerlukan bantuan dana pada masa tanam sampai dengan masa panen serta kebijakan adanya insentif bagi para petani untuk memperoleh harga obat dan pupuk yang terjangkau dan tercukupi stock-nya.

Tabel 2. Tabel Analisis Potensi Ekonomi Lokal Samarinda Ilir

\begin{tabular}{|c|c|}
\hline Kelompok Strategis & Potensi Ekonomi Lokal \\
\hline 1. Petani kecil & $\begin{array}{l}\text { Mata pencaharian masyarakat di desa } \\
\text { Menjadi komoditas politik } \\
\text { Tingkat partisipasi tinggi }\end{array}$ \\
\hline 2. Pengrajin & $\begin{array}{l}\text { Peluang usaha bagi masyarakat di beberapa kelurahan } \\
\text { Sumber pendapatan tambahan } \\
\text { Dukungan pengembangan pariwisata }\end{array}$ \\
\hline 3. Pedagang & $\begin{array}{l}\text { Peluang usaha bagi masyarakat di perkotaan, pinggiran dan desa } \\
\text { Memasok kebutuhan masyarakat } \\
\text { Pemasaran hasil pertanian }\end{array}$ \\
\hline 4. Peternak & $\begin{array}{l}\text { Menjadi mata pencaharian tambahan para petani } \\
\text { Peluang usaha bagi sebagian besar petani }\end{array}$ \\
\hline 5. Pengusaha kecil dan menengah & $\begin{array}{l}\text { Jumlahnya relatif banyak dan ditemukan di daerah pinggiran dan perkotaan } \\
\text { Menciptakan lapangan kerja } \\
\text { Berkontribusi terhadap pendapatan daerah } \\
\text { Peluang usaha bagi ibu-ibu rumah tangga }\end{array}$ \\
\hline 6. Pekerja bangunan & $\begin{array}{l}\text { Peluang usaha bagi masyarakat pendatang yang bermukim di perkotaan } \\
\text { Sumber pendapatan keluarga }\end{array}$ \\
\hline 7. Industri rumah tangga & $\begin{array}{l}\text { Relatif banyak jumlah variasi produk yang dihasilkan dari industri rumah tangga } \\
\text { Peluang usaha bagi ibu-ibu rumah tangga } \\
\text { Sumber pendapatan tambahan } \\
\text { Berkontribusi terhadap pengembangan pariwisata }\end{array}$ \\
\hline 8. Jasa pencucian & $\begin{array}{l}\text { Peluang usaha bagi ibu-ibu rumah tangga } \\
\text { Sumber pendapatan keluarga } \\
\text { Ketrampilan dan alat yang digunakan relatif konvensional } \\
\text { Proses pengerjaan secara tradisional }\end{array}$ \\
\hline 9. Perangkat desa/ kelurahan & $\begin{array}{l}\text { Memiliki otoritas perencanaan dan pelaksanaan pembangunan desa } \\
\text { Mediator antara pihak dunia usaha - dengan masyarakat dan pemerintah desa } \\
\text { Peraturan desa dan kebijakan pemerintah desa }\end{array}$ \\
\hline
\end{tabular}

Sumber: Data Olahan Hasil FGD 
4) Pelatihan dan pembinaan

Manyarakat membutuhkan pembinaan dan bantuan pelatihan ketrampilan dalam bidang teknis tertentu dari pemerintah daerah maupun perusahaan secara berkelanjutan guna meningkatkan kualitas manajemen usaha yang digeluti. Bentuk pengembangan dapat dilakukan melalui pemberikan penyuluhan dan bimbingan sesuai dengan kebutuhan yang mereka perlukan secara berkelanjutan.

Kebutuhan kelompok usaha pengrajin, usaha kecil, industri rumah tangga berupa pengembangan ketrampilan di bidang pembukuan, standarisasi kualitas produk, bantuan pemasaran produk, manajemen usaha dan kewirausahaan.

5) Bantuan promosi pemasaran

Barang/jasa yang menjadi komoditas utama dari usaha kecil masyarakat membutuhkan bantuan promosi dari pemerintah daerah dan perusahaan mitra guna mendongkrak volume penjualan dan penerimaan masyarakat. Pemasaran produk merupakan hal yang sulit bagi usaha kecil apalagi pemula. Oleh sebab itu diperlukan campur tangan instansi terkait untuk memperkenalkan produk mereka melalui kegiatan, seperti pameran.

6) Kebijakan daerah guna kelancaran usaha kecil Dibutuhkan kebijakan daerah yang memiliki keberpihakkan kepada usaha kecil yang berbasis pada pengembangan potensi ekonomi lokal, sehingga membuka kesempatan kerja bagi masyarakat setempat.

7) Kemudahan akses perbankan

Usaha kecil, mikro yang digeluti masyarakat sangat membutuhkan dukungan pemerintah daerah untuk memperoleh kemudahan akses perbankan atau jaminan kredit, sehingga mereka memperoleh sumber pendanaan guna pengembangan usahanya.

8) Kemitraan dengan perusahaan besar.

Masyarakat berharap bahwa usaha yang digelutinya menjadi mitra binaan dari perusahaanperusahaan besar yang beroperasi di Kota Samarinda. Dengan demikian masyarakat dapat memperoleh manfaat pembinaan manajemen usaha atas keberadaan perusahaan mitra.

Berdasarkan hasil analisis dengan menggunakan matriks interaksi antara potensi dasar (basic potentials) dan potensi turunan (derived potentials), maka urutan sektor usaha unggulan yang memiliki skor tertinggi berada pada sektor usaha:

1) Perdagangan. Sektor usaha ini paling banyak dimasuki oleh masyarakat Samarinda Ilir karena hambatan untuk masuk sangat rendah. Obyek komoditas yang paling banyak diperdagangkan oleh masyarakat antar lain makanan, minuman, sembako, dan hasil pertanian. Dilihat dari cara masyarakat berdagang adalah secara keliling, asongan, kaki lima, menetap dalam bentuk kios/warung/toko. Usaha ini dapat dikembangkan dihampir seluruh desa/kelurahan di Samarinda Ilir kecuali kelurahan Makroman dan Sindangsari.

2) Industri rumah tangga dan jasa. Industri rumah tangga yang banyak ditemui adalah industri kerajinan berupa manik-manik, industri tahutempe, aneka kripik/krupuk udang dan ikan, susu kedelai, jamu gendong, kue kering dan pandai besi, serta galangan kapal. Jasa yang menjadi mata pencaharian masyarakat adalah pertukangan, salon, jahit, bengkel, cuci pakaian. Desa/kelurahan yang memiliki potensi sektor usaha industri kecil dan jasa adalah Pulau Atas, Sungai Kapih, Sungai Pinang Luar, Sambutan, Karang Mumus dan Pelabuhan.

3) Pertanian dan peternakan. Hasil produksi pertanian berupa beras dan sayuran menjadi salah satu potensi sumberdaya ekonomi yang dapat dikembangkan dan memiliki peluang membuka kesempatan usaha disektor hulu-hilir yang pada akhirnya dapat menciptakan peluang kerja bagi masyarakat setempat. Desa/kelurahan yang memiliki potensi sektor usaha pertanian dan peternakan adalah Makroman dan Sindangsari.

Produk Unggulan yang berhasil diidentifikasi di Kecamatan Samarinda Ilir sebagai berikut:

1) Minuman tradisional

Jamu gendong merupakan minuman tradisional yang terbuat dari rempah-rempah berupa kencur, jahe, kunyit, sirih, yang dicampur dengan beras. Kelompok penjual jamu gendongan terpusat di desa/kelurahan Pasar Pagi, Karang Mumus, Pelabuhan, dan Sungai Pinang Dalam. Pembeli minuman ini tidak hanya masyarakat Samarinda Ilir melainkan juga masyarakat dari Kecamatan lainnya.

Minuman tradisional lainnya yang menjadi usaha masyarakat adalah susu kedelai. Meningkatnya permintaan akan produk ini memberikan multiplier effect pada sektor pendukung utamanya yakni penyediaan bahan baku berupa kedelai, sehingga mendorong kegiatan pertanian palawija dapat ditingkatkan lebih baik lagi. Pengembangan ekonomi lokal melalui pengembangan produk unggulan berupa minuman tradisional ini dapat dioptimalkan manfaatnya bagi masyarakat jika didukung dengan kebijakan Pemerintah Kota Samarinda melalui penetapan 'Gerakan Pola Hidup Sehat dan Cinta Produk Lokal'. 
Meningkatnya permintaan terhadap minuman tradisional meningkatkan peluang usaha masyarakat dan membuka lapangan pekerjaan bagi masyarakat.

2) Aneka makanan tradisional

Amplang, kue kering, tahu-tempe dan kue tradisional lainnya merupakan produk lokal yang potensial untuk dikembangkan menjadi suatu usaha yang membuka lapangan kerja bagi masyarakat. Produk ini memiliki prospek bisnis lebih baik karena ditetapkan menjadi makanan khas Samarinda yang sudah mulai populer di masyarakat sebagai oleh-oleh. Pemerintah Samarinda telah menetapkan Kecamatan Samarinda Ilir sebagai pusat wisata kuliner. Prospek bisnis ini dapat mendorong terciptanya bisnis turunan di sektor peternakan dan pertanian untuk mendukung ketersediaan bahan baku.

3) Kerajinan

Kerajian berbahan dasar dari manik-manik dan kain bludru yang disulam dalam bentuk barang tertentu tergolong kerajinan tradisional. Outputnya berupa baju adat dayak, tas tangan, gantungan kunci dan lain sebagainya. Jumlah permintaan cukup baik dan didukung dengan ketrampilan SDM maupun sumber daya bahan bahan baku menjadikan kerajinan manik-manik dijumpai di hampir seluruh desa dan sebagai sentra pembuatan souvenir dari Samarinda. Ketrampilan meronce manik ini juga diajarkan di sekolah-sekolah dasar sebagai pengetahuan muatan lokal.

4) Hasil pertanian \& ternak

Padi gunung, padi lahan basah dan sayuran merupakan hasil utama desa Makroman dan Sindangsari merupakan pemasok terbesar kebutuhan pangan masyarakat Samarinda pada umumnya. Padi gunung memiliki kualitas tinggi dan bersih serta jumlah produksi dapat mencapai antara 3,5-4 ton per hektar khususnya.

Sapi merupakan salah hewan ternak yang dikembangkan secara berkelompok. Sistim pengelolaannya digulir ke tiap KK. Jumlah ternak dapat mencapai 50 ekor dan tiap tahun berkembang biak rata-rata satu sapi memiliki 1-2 anaknya. Keberadaan ternak sapi yang cukup banyak di daerah Samarinda Ilir ini, menjadikan daerah ini sebagai pemasok kebutuhan daging masyarakat Samarinda.

5) Industri kecil dan jasa

Industri galangan kapal mulai tumbuh dan berkembang di bantaran Sungai Mahakam dan paling banyak ditemukan di wilayah kelurahan Pulau Atas, Sambutan. Tumbuh dan berkembangnya industri galangan kapal membuka peluang kerja bagi masyarakat di sekitarnya. Jasa pertukangan banyak ditawarkan oleh masyarakat pendatang yang bermukim di Samarinda Ilir.

Semua produk unggulan tersebut diatas merupakan potensi ekonomi produktif yang dapat dikembangkan guna menciptakan lapangan kerja bagi masyarakat yang pada akhirnya dapat mengatasi masalah kemiskinan di daerah Samarinda Ilir. Produk-produk unggulan tersebut sebagai model penciptaan lapangan kerja bagi masyarakat Samarinda Ilir. Produk unggulan yang dipilih harus merupakan produk unggulan yang berdaya tarik dan berdaya saing tinggi. Daya tarik sektor usaha makanan dan minuman tradisional yakni sudah terbukti mampu bertahan pada kondisi krisis, jumlah permintaan terus meningkat, tidak tergerus dengan berubahnya jaman karena memiliki segmen pasar tersendiri. Minuman dan makanan tradisional diolah secara alami dan tanpa pengawet. Makanan tradisional memiliki daya tarik dalam hal berbahan dasar bahan organik, memiliki cita rasa variatif, renyah dan harga terjangkau.

Kerajinan manik-manik menjadi usaha yang cukup prospektif karena memperoleh dukungan dari Pemerintah Kota Samarinda dengan ditetapkan sebagai salah satu barang souvenir Kota Samarinda. Daya tarik terletak pada model, bentuk yang menarik dengan berbagai variasi output produk sesuai kebutuhan masyarakat dan sering diikutkan dalam ajang pameran ataupun promosi daerah maupun nasional. Daya tarik hasil pertanian dan peternakan dari Samarinda Ilir adalah proses penanaman dan pemeliharaan yang lebih berorientasi pada cara konvensional yang ramah lingkungan dan menggunakan bahan-bahan organik.

Produk-produk unggulan masyarakat Kecamatan Samarinda Ilir memiliki daya saing tinggi dibandingkan dengan produk-produk serupa dari daerah lain, karena harga jual sangat kompetitif, cita rasa bagus, cara pemrosesannya higienis dan bisnis dijalankan secara etis, serta adanya kemauan dari masyarakat untuk terus belajar meningkatkan kualitas usaha dan pelayanannya.

Strategi pengembangan potensi ekonomi lokal daerah adalah dengan: 1) mengoptimalkan potensi yang menjadi produk unggulan dan dituangkan dalam kebijakan strategis Pemerintah Kota Samarinda. 2) Melakukan penguatan usaha produktif secara komprehensif lintas sektor satuan kerja perangkat daerah (SKPD) yang ditujukan kepada usaha-usaha kecil, perdagangan, industri rumah tangga yang berbasis kegiatan sektor primer yakni pertanian secara berkelanjutan. 3) Adanya komitmen bersama antara Pemerintah Kota Samarinda-masyarakat-pelaku usaha untuk pengentasan masyarakat miskin dari aspek pendapatan maupun non pendapatan. 


\section{SIMPULAN DAN SARAN}

Berdasarkan hasil analisis dan pembahasan secara umum dapat disimpulkan bahwa potensi sumberdaya ekonomi lokal yang berdaya tarik dan berdaya saing tinggi yang dapat membuka lapangan kerja bagi masyarakat adalah:

1) Ditinjau dari sektor usahanya berturut-turut berdasar skala prioritasnya: perdagangan, industri rumah tangga dan jasa, pertanian dan peternakan.

2) Ditinjau dari Jenis produk unggulannya berturutturut berdasar skala prioritasnya: makanan \& minuman tradisional, kerajinan manik-manik, beras, sayuran \& daging sapi, jasa pertukangan.

3) Ditinjau dari unggulan potensi lokal masingmasing desa/kelurahan: perdagangan dan industri rumah tangga dan jasa potensial dikembangkan di Kelurahan Sungai Pinang Luar, Sido Mulyo, Sido Damai, Pasar Pagi, Pelabuhan, Karang Mumus, Selili, Sungai Dama, Pulau Atas, Sungai Kapih dan Sambutan; sedangkan pertanian \& peternakan potensial dikembangkan di kelurahan Makroman dan Sindangsari.

Hasil penelitian yang diperoleh mendasari disampaikannyha beberapa saran sebagai berikut:

1) Diperlukan tindakan perencanaan pengembangan ekonomi lokal secara terpadu dan berkelanjutan dari pihak pemerintah daerah dalam menguatkan kemampuan sektor usaha informal.

2) Peningkatan koordinasi lintas sektor antar SKPD Kota Samarinda terkait dengan upaya pengentasan kemiskinan melalui penciptaan lapangan kerja di sektor usaha-usaha produktif yang merupakan produk unggulan yang memiliki daya tarik dan daya saing tinggi.

3) Perlu adanya evaluasi dan penajaman berbagai program pengentasan kemiskinan yang telah dijalankan oleh pemerintah Kota Samarinda selama ini yakni program yang mampu mendorong kemandirian ekonomi.

4) Tempat pengembangan sentra sentra produk unggulan yang berbasis pada potensi lokal seperti sektor pertanian dan agri bisnis di kelurahan Sindang Sari, Makroman dan Sambutan. Sentra pengembangan kerajinan di kelurahan Sungai Kapih, sedangkan sentra perdagangan di daerah Pasar Pagi.

\section{DAFTAR REFERENSI}

Afifi, M. 2007. Pemberdayaan Masyarakat Melalui Pengembangan Ekonomi Lokal: Studi Kasus Pengembangan Budidaya Rumput Laut di Kabupaten Dompu Nusa Tenggara Barat.
Makalah disampaikan dalam International Conference "Persidangan Antarbangsa Pembangunan Aceh (PAPA $2^{\text {nd }}$ )" Universitas Malikussaleh Lhokseumawe 29-30 Desember 2007.

Blakely \& Bradshaw. 2002. Planning Local Economic Development, Theory and Practice. California: Sage Publication.

BPS. 2010. Hasil Sensus Penduduk 2010 Kota Samarinda: Data Agregat Per Kecamatan. Badan Pusat Statistik. Kota Samarinda.

Dendi, A. H. R. \& Mahman, R. 2007. Forum Pengembangan Ekonomi Lokal-konsep, Strategi dan Metode; Perspektif dan Pengalaman Nusa Tenggara. GTZ-GLG dan Departemen Dalam Negeri Indonesia.

ILO. 2004. Seri Rekomendasi Kebijakan: Kerja Layak dan Penanggulangan Kemiskinan di Indonesia.

Indra, H. 6 April 2009. Akibat Banyak Pendatang: Angka Kemiskinan di Samarinda Berkurang 2 Ribu RTS. KaltimPos.co.id.

Indratno, I. \& Agustina. I. H. 2005. Studi Kemampuan Masyarakat Dalam Pengembangan Ekonomi Lokal Sebagai Upaya Pengentasan Kemiskinan. MIMBAR, Jurnal Sosial dan Pembangunan, 21(3): 416-429.

Ismawan, B. 1992. Pengembangan Swadaya Nasional Tinjauan ke Arah Persepsi yang Utuh. LP3ES diterbitkan untuk Participatory Development Forum.

Korten. D. C. \& Syahrir. 1988. Pembangunan Berdimensi Kerakyatan. Jakarta: Yayasan Obor Indonesia.

Mubyarto. 1984. Strategi Pembangunan Pedesaan. Yogyakarta: P3PK UGM.

Sade, S. Rabu, 8 Desember 2010. Keluarga Miskin Samarinda Capai 28.050 KK. Samarinda Pos Online.

Sarman, M. \& Sajogyo. 2000. Masalah Penanggulangan Kemiskinan Refleksi dari Kawasan Timur Indonesia. Universitas Sumatera Utara, Medan: Puspa Swara.

Suyono, E. 2006. Pengaruh Program Kemitraan Bagi Pengembangan Ekonomi Lokal (KPEL) Terhadap Pendapatan Petani Budidaya Ulat Sutera di Kabupaten Wonosobo. Thesis tidak dipublikasikan.Universitas Diponegoro.

Syahari. J. 18 Januari 2013. Pemerintah Bagikan 2.564 Kartu RTSM. Antara New.com. Kalimantan Timur.

Zaini, A. Kamis 3 Januari 2013. KALIMANTAN TIMUR: Penurunan Angka Kemiskinan Belum Signifikan. Bisnis.com. 